\title{
REVIEWS
}

Reviews of books, reports, papers and other publications should be sent to J. Walter Giles, Book Review Co-ordinator, Department of Lands and Forests, Pembroke, Ont. Please mention that you saw the review in the Forestry Chronicle when parchasing books from publishers.

\section{Economics of Forest Management}

by A. L. Best. (Bulletin 112, Forestry Branch, Dept. of Northern Affairs and Natural Resources) Queen's Printer, Ottawa, 95 pp., illus., 1954. $\$ 2.00$.

The sub-title: "A study of the costs of sustained yield forest management on the Sault au Cochon Management Unit at Forestville, Quebec", describes this work much better than the general title which may be misleading.

This large brochure replete with statistical tables, graphs, and maps of management units, is presented in a clear, attractive format. The chapters are divided to cover the following aspects: purposes of the study; description of the area; management of the unit; cost structure; and economic analysis. The appendices supplement the foregoing with forest management tables, improvement standards, sample camp operations, and cost data.

The particular subject has long been neglected, so long in fact, that one frequently hears that sentiment has replaced economics in the field of forest management. Best's work is valuable as illustrating the long-term view which management should have in order that immediate decisions can be appraised on either the long or short term basis.

The job has been well done. Industrial foresters whose work is at all related to costs will find the study stimulating. We wonder, however, if a government department has not accepted an impossible challenge- to make an economic survey of a company without revealing company costs? Just what the figures mean is somewhat puzzling. It is hard to reconcile " . . . in presenting cost figures in the accompanying schedules, illustrative figures only are used . .." with the definite conclusions given in the chapter on economic analysis.

In the cutting and hauling schedules, average cost per cord values have been established for each minor watershed. It is thought that topographical and forest variations within a watershed may result in considerable cost variations, in fact there may be greater variations within a watershed than between the averages of watersheds. It is true that averages can be obtained for a watershed, yet the use of the average can result in an embarrassing variation from year to year unless careful planning is done to see that the annual average of all camp conditions is an average for the management unit.

Despite the foregoing strictures, the work will have been worthwhile if it draws attention to the fact that long-range economic surveys are both possible and necessary, and if it sets up a form for making the survey which other foresters will follow. Mr. Best, like most initiators in a subject field, merits congratulations.

Geo. R. SONLEY 


\section{Hardwood Pulping in the Northeast}

Northeastern Wood Utilization Council Bulletin 43, Box 1577 New Haven Conn. 48 pp. $1955, \$ 2.00$.

Hardwood pulping in the northeast presents eleven papers covering the subject from resources availability and procurement to actual pulping processes. Special emphasis is placed by nearly all speakers on the neutral sulphite semichemical process which holds great promise for future development in hardwood pulping. High yields and adaptability to bleaching make this process economically superior to others now in use, and should assure increased use of hardwoods for pulp in the future. Primary use of the pulp is in nine-point board and building products, but bleached pulp will be used increasingly in book and magazine papers, bond and fine papers, greaseproof and glassine papers.

Chemiground pulps from hardwoods have been used recently as a component of newsprint.

This bulletin is of interest to anyone concerned with hardwood utilization and shows clearly the future trend in pulping of species and material heretofore considered as unmerchantable.

\section{J. WALter Giles}

\section{Forest Hygiene in Great Britain}

by W.R. Day, 1955. University of Toronto Forestry Bulletin No. 4, 26 pp., University of Toronto Press, $\$ 1.00$.

Though the popular concept of the meaning of the word hygiene is one of personal cleanliness, the Oxford Dictionary defines it as: "Knowledge or practice relating to the maintenance of health" and the author states in his introduction that "the study of it necessitates attention to anything which affects the conditions of life for the forest". This naturally opens up a tremendous field, and he indicates the effects of history, land classes, education, races within species, disease, environment, successional development and volume of rooting space.

Perhaps the most important feature of this work is the recognition of the constant interplay of these factors and the necessity for realizing that "planting is the initiation of a development", that biological understanding is of even greater importance to the practicing forester than technical knowledge and that education in forestry is really a process of learning from practice.

This last statement is unquestionably true, but still there is ample opportunity for Canadian foresters to profit by the costly experience of British foresters and-if we are wise enough-avoid some of the more serious mistakes which have been made. In many cases these same mistakes have already been repeated in Canada, but there may yet be time to correct some of them before it is too late if we recognize them now.

This work should be in the library of every practicing forester, not only because it indicates the more serious errors which are made in the establishment and management of woodlands, but because it brings home the necessity of asking oneself before undertaking any forestry operation-What am I really doing?

A. S. L. BARNeS 


\section{U B C Forester, 1955}

Forest Club, University of British Columbia, Vancouver, B.C. 100 pp. While primarily of interest to the students and alumni of UBC, this wellillustrated student magazine contains a few articles of general interest. This silver anniversary issue of the Forester is dedicated to the Canadian Forestry Association and contains a fine salute to the work of that organization. An excellent article on the history of railway logging by Robert E. Swanson, Chief Inspector of Railways for B.C., provides the main contrast to the predominantly student articles on Campus activities and Club accomplishments. Photographs and illustrations, which are liberally displayed in the publication, are of fine quality and add materially to the magazine.

\section{The Annual Ring, 1955}

Foresters' Club, University of Toronto, Toronto, Ontario, 72 pp. $\$ 1.00$. In its eighth edition, the Annual Ring is presented as a well-balanced publication containing several articles of general interest to Canadian foresters. W. Howard Rapson's article on the Hardwood Revolution in the Pulp and Paper Industry and A. S. Michell's discussion of The Package Handling of Lumber might be singled out for particular comment. About half the magazine is devoted to articles and the remainder to news of student and alumni affairs. Advertising is restricted to eleven pages at the front and back. Illustrations, while not plentiful, are well chosen and clearly reproduced. D. C. Fayle's drawings are worthy of note. Only changes of address and additions are included in this year's Graduate Directory; no doubt this implies that those interested in keeping up to date with alumni changes are regular subscribers and will be in possession of past issues-a reasonable assumption.

\section{J. WALTER GILES}

\section{CURRENT PUBLICATIONS}

GENERAL

FAO: Activities of the Food and Agriculture Organization under the expanded Technical Assistance Program 1953/54, UN, Rome 1954.

FAO: Agriculture, Fisheries, Forestry and Nutrition in Canada, 1954/55 Biennial Progress and Program Report to FAO of the UN, 1955.

Gilmour, J. D.: Allocating Forest Land to Best Use (Comment): In The American Journal of Economics and Sociology, Vol. 14, No. 3, April, 1955.

Godwin, Gordon: How are you fixed for wood? (Speech to Rotary Club of Woodstock, Ont.) C.P.P.A., Montreal, 1955.

Kingston, J. T. B.: Statistical Record of the Lumber Industry in B.C. Part II, Sec. 2. Victoria, B.C., 1955.

Kingston, J. T. B.: Statistical Record of the Pulp and Paper Industry in B.C., Part II, Sec. 3. Victoria, B.C., 1955.

Pulp and Paper Industry of British Columbia: The Changing Forest Industry. Vancouver, B.C., 1954.

Saskatchewan Dept. Natural Resources: Saskatchewan's Forests, pp 129, 1955.

Simonen, M. E.: Forestry Dictionary: Swedish-English-German-French. Swedish Forestry Association, Regerengsgaten 18, Stockholm C, Sweden. 284 pp., 1954, 35 crowns. 